\title{
Frederico Carlos Hoehne: viagens e orquídeas
}

\author{
José Luiz de Andrade Franco* \\ jldafranco@terra.com.br \\ José Augusto Drummond** \\ jaldrummond@uol.com.br
}

Resumo: Este texto examina, por meio das impressões de viagem do botânico Frederico Carlos Hoehne (1882-1959), seu pensamento e sua perspectiva estética relacionados com a proteção da natureza. Resume uma extensa viagem de campo "imaginária" do autor pelo território nacional, com foco em plantas, paisagens, ecossistemas e biomas. Hoehne foi um pioneiro no tema entre os cientistas brasileiros do século XX e contribuiu para a emergência de uma consciência ambientalista no Brasil. A sua abordagem combinava a ciência com argumentos estéticos e a percepção de que a natureza devia desempenhar um papel importante na constituição da identidade nacional brasileira.

PALAVRAS-CHAVE: proteção à natureza, diversidade biológica, pesquisa botânica, história da ciência, Brasil.

O objetivo deste artigo é contribuir, por meio da análise da narrativa realizada por Frederico Carlos Hoehn, um dos primeiros e ainda um dos maiores botânicos brasileiros, sobre as suas viagens pelo Brasil, para a "redescoberta" do pensamento e da perspectiva estética relacionados com a proteção à natureza.

O texto apresenta primeiro alguns dados biográficos de Hoehne e, em seguida, explora as dimensões presentes em suas observações e reflexões acerca da natureza: sobre a sua beleza, sobre o conhecimento a seu respeito e sobre as possibilidades do seu uso "racional". É dada atenção especial às suas preocupações e propostas concernentes à conservação do patrimônio natural brasileiro. Por fim, é apresentada a preocupação de Hoehne em formular estratégias que vinculassem a valorização da natureza e da ciência à construção de um projeto de nação e à afirmação de uma identidade nacional brasileira.

\footnotetext{
* Pesquisador associado do Centro de Desenvolvimento Sustentável da Universidade de Brasilia.

** Professor do Centro de Desenvolvimento Sustentável da Universidade de Brasília.
} 


\section{DADOS BIOGRÁFICOS}

Mineiro de Juiz de Fora, de ascendência alemã e origem humilde, Frederico Carlos Hoehne (1882-1959) não ultrapassou o nível secundário do ensino oficial. No entanto, movido por uma rígida autodisciplina, tornouse um autodidata devotado à pesquisa nas áreas de botânica, biogeografia e ecologia. Ao estilo dos viajantes naturalistas do século XIX, percorreu todas as regiões do Brasil, coletou farto material para a organização de herbários e contribuiu grandemente para a classificação da flora nativa, especialmente das orquídeas, o seu interesse principal. A sua vasta produção científica mais de quinhentos artigos de divulgação, cerca de cinqüenta conferências, uma centena de trabalhos e monografias científicas relacionadas à botânica sistemática - alcançou reconhecimento internacional. Foi membro honorário da American Orchid Society, distinção conferida a poucos cientistas no mundo inteiro, e recebeu o título de doutor honoris causa pela Universidade de Göttingen, na Alemanha, em 1929 (Ferri, 1994; DeAn, 1996).

Hoehne iniciou, em 1907, a sua vida profissional como funcionário público - foi admitido como jardineiro-chefe do Museu Nacional do Rio de Janeiro. Em meados de 1908, fez a sua primeira grande excursão de campo, acompanhando, como botânico, a Comissão Rondon, no Mato Grosso e no Amazonas. Em 1910, retornou ao Mato Grosso, em companhia dos botânicos Hermano e Geraldo Kuhlmann e, em 1913, como integrante da Expedição Roosevelt-Rondon. Ao longo da sua vida profissional, viajou também por Minas Gerais, São Paulo, Paraná, Santa Catarina, Rio Grande do Sul e por todo o litoral brasileiro, tornando-se um profundo conhecedor da biogeografia do país. Ao todo foram quinze expedições científicas, nas quais ele e os seus colaboradores coletaram pelo menos 10 mil espécimes vegetais, correspondendo a pelo menos 4 mil espécies distintas, das quais cerca de duzentas eram novas para a ciência. Assim, Hoehne realizou plenamente o seu sonho juvenil de viajar pelo território brasileiro e descobrir plantas novas para a ciência. Foi ainda mais longe: a título de homenagem, dezenas de outras plantas da flora nativa brasileira, também novas para a ciência, foram batizadas com o seu nome, por iniciativa de colegas, assistentes e admiradores.

Foi em São Paulo, no entanto, que Hoehne se fixou profissionalmente e manteve uma atuação destacada no que diz respeito à proteção da natureza. A sua carreira esteve intimamente vinculada ao surgimento do Instituto de Botânica do Estado de São Paulo. De início, em 1917, foi convidado pelo 
diretor do Serviço Sanitário para organizar um horto de cultura e aclimatação de plantas medicinais, mas dedicou-se a um projeto um pouco mais amplo, montando uma Seção de Botânica no Instituto Butantã. Mais tarde, em 1923, essa seção transferiu-se para o Museu Paulista. Em 1928, houve mais uma mudança, agora para o Instituto Biológico de Defesa Agrícola e Animal, passando a denominar-se Seção de Botânica e Agronomia. A seção ganhou mais autonomia em 1938, quando se transformou em Departamento de Botânica, subordinado diretamente à Secretaria de Agricultura, Indústria e Comércio. Finalmente, em 1942, o departamento se transformou no atual Instituto de Botânica. Hoehne esteve sempre à frente, como diretor da administração da seção e depois do Instituto, que se fixou no atual Jardim Botânico de São Paulo, fundado em 1928, por influência sua. Foi responsável ainda pela gestão da Estação Biológica do Alto da Serra, exemplo de espaço dedicado à conservação da natureza e à atividade científica. Trabalhou incansavelmente até 1952, quando, ao atingir a idade de 70 anos, recebeu aposentadoria compulsória (FERRI, 1994).

\section{“EXCURSäo MENTAL” pelo país}

As viagens pelo Brasil realizadas por Hoehne, bem como o seu conhecimento sobre - e as suas preocupações com - a flora e fauna nativas, foram sintetizadas na publicação Iconografia das orchidáceas do Brasil, de 1949, no capítulo intitulado "Excursão mental pelo País". Ele quis, basicamente, elucidar quais são, onde estão e como vivem as orquidáceas nativas dos diversos rincões do Brasil, por meio da narrativa de uma excursão imaginária. No entanto, à medida que realizamos a viagem proposta, são discutidas também questões mais gerais, relacionadas à fitogeografia ou à proteção e uso racional da natureza. Em princípio, ficava acertado que

a excursão será mental, estribada em fatos e observações feitas durante as nossas excursões e viagens levadas a efeito desde 1895 até 1946, espaçadas e intercaladas sempre de trabalhos longos de laboratório. Para melhor compreensão e comparação do que existia e do que agora existe, mencionaremos, onde for aconselhável, a época em que registramos as impressões. Fá-lo-emos, entretanto, sem nos atermos à sua ordem cronológica, mas seguindo rumos geográficos para também darmos uma idéia da imensidão do nosso território. Partiremos, portanto, de São Paulo e tornaremos a ele sem sairmos do conforto do lar com o nosso físico, viajando com o nosso espírito. (HoEHNE, 1949, p. 52-53)

José L. de A. Franco; José A. Drummond. Frederico Carlos Hoehne: viagens e orquídeas 
Logo de início, Hoehne constatava que o papel econômico que as orquidáceas podiam desempenhar ainda não tinha sido compreendido, sendo a sua exploração completamente irracional:

Essas plantas têm sido daqui tiradas, [...], por estrangeiros e nacionais, sem que o fisco e mesmo os possuidores das terras tivessem tomado nota ou intervindo para o obstar. Todavia, é incontestável que o seu valor é maior do que o das madeiras em muitas regiões. É enorme o seu apreço comercial e precioso, portanto, o papel que deveriam desempenhar na economia nacional. É comum encontrarem-se árvores que ostentam espécimes bastantes para fazerem subir o valor de uma floresta ao décuplo daquilo que ela poderá valer pelo seu conteúdo de madeira ou lenha. Todavia, essas plantas são retiradas, levadas e vendidas sem que daí advenha, ao proprietário ou ainda ao governo do país, qualquer vantagem. (Hoenne, 1949, p. 50-51)

As orquidáceas podiam e deviam ser coletadas, cultivadas e mesmo melhoradas, embora o sucesso nesses empreendimentos exigisse um cuidado e um conhecimento profundos. Era preciso tomar cuidado para que a exploração descontrolada não viesse a comprometer a reprodução da variada flora orquidófila do país, em prejuízo da coletividade e principalmente das gerações vindouras. Hoehne alertava:

No que concerne à distribuição geográfica de algumas espécies mais preciosas, constata-se que muitas já estão completamente exterminadas em localidades onde, ainda há um século atrás, podiam ser colhidas em enormes quantidades. Não fosse a grande dispersão de muitas delas, sem dúvida já teríamos de lamentar o desaparecimento de todas as que são mais cobiçadas pelos colecionadores nacionais e estrangeiros. (Hoehne, 1949, p. 51)

Havia, para Hoehne, um aspecto estético na apreciação das orquídeas, em particular, e da natureza, de uma perspectiva mais ampla. Ele era, ao mesmo tempo, um homem de ciência e um romântico, um apaixonado pelos coloridos e pelas harmonias do mundo natural. As orquídeas desempenhavam,

[...] com seu perianto, exibição não muito diferente daquela que a donzela faz quando chega a idade em que deve escolher o seu namorado. Essa exibição, da parte das orquidáceas, como de outras plantas, destina-se também, como ali, ao embelezamento do ambiente, ao proporcionamento da alegria da natureza. Eé justamente por isso que deparamos com tantas 
formas, com tão variados aprestos. Tudo se esforça na natureza para ser diferente, para concorrer para a diversidade dos formatos e dos coloridos [...]. (Hoenne, 1949, p. 52)

O mundo se revelava como um ser vivo e dotado de finalidade. A perfeição se realizava por meio da expressão da beleza:

Permitam-nos mais um devaneio. Se literato ou poeta fôssemos, diríamos que todas estas belezas, esta harmonia que observamos na natureza, é resultado, efeito da luz, exteriorização da vida, em tudo manifesta, em todos uma só. Essa vida - harmonia e beleza - surge em todos os recantos, nos ensolarados e sombrios, e traduz, em cada ambiente, uma finalidade que - aparentemente egoísta, por natureza exercida com requintado e insofismável desejo de alijar e excluir rivais e comparsas - resulta no maravilhoso entrosamento de interesses, que, em realidade, é a energia universal mantenedora de todas as coisas e de todas as espécies, causa do equilíbrio, que ao observador arguto não escapa. (Hothne, 1949, p. 52-53)

Para além da desordem e da competição, prevalecia a cooperação. A natureza expressava-se como um todo harmônico. A metáfora judaico-cristã da criação e do homem como o seu centro era retomada por Hoehne, porém, na sua hermenêutica, a humanidade aparecia como parte integrante e integrada ao todo. Não havia a possibilidade de um conhecimento produzido de fora, à parte do mundo:

O homem, rei deste planeta por ordenação divina, é também elemento integrante desse mundo, todavia acredita, ingenuamente, que o pode compreender e julga-se apto para tudo interpretar. De fato, tudo estuda e esquadrinha, sonda e contempla detalhes e minúcias, mas do mistério conhece ainda muito pouco. Se parte é do todo, como poderia compreendê-lo, como conseguiria abrangê-lo, excluindo-se?! Todavia, o homem é criatura divina, é também um criador. Com utilização do existente, cria novas espécies, formas e variedades, e o faz com relativa perfeição, quando aplica a sua inteligência ao trabalho. Dentro das leis eternas preexistentes, sujeito a elas o realiza para seu maior proveito, nem sempre, porém, para o aperfeiçoamento do todo e felicidade geral. (HoEHNE, 1949, p. 52)

Antes de iniciarmos a "excursão mental" proposta por Hoehne, é importante compreender o papel desempenhado pela estética em suas reflexões sobre o mundo natural. Em outra obra sua, As plantas ornamentais

José L. de A. Franco; José A. Drummond. Frederico Carlos Hoehne: viagens e orquídeas 
da flora brasílica, ele procurou definir de modo mais completo a estética e a sua relação com a natureza. Citava Platão, Aristóteles, Kant e Schelling, com o propósito de demonstrar que a apreciação estética era um sentimento elevado, capaz de impulsionar o homem no caminho da transcendência:

O senso estético não é, porém, peculiar, isto é, desenvolvido em todos os homens. Ele é natural e próprio dos seres elevados, peculiar e bem desenvolvido nos espíritos cultos e aprimorados, que cogitam das coisas transcendentes e sublimes [...].

Educar o espírito e aperfeiçoar o moral dos nossos semelhantes é convertê-los em apóstolos do bem, transformá-los em seres capacitados para compreender e amar a estética.

O estético alimenta o espírito, eleva a alma, não só de uma pessoa e em prejuízo de outras, mas de todas, em proveito da coletividade, porque o belo e o bom o são, simultaneamente, para todos, sem prejuízo de quem quer que seja. (HoEHNE, 1930, p. 23)

Esse sentimento de unidade e harmonia era proporcionado, sobretudo, pelo convívio com a natureza, que devia guiar e conduzir a humanidade ao prazer e à alegria, como modelo maior de perfeição:

Se detidamente analisarmos e observarmos as leis que regem o cosmo, se examinarmos os detalhes dos componentes da flora e da fauna $e$ pesquisarmos a simbiose e a mútua dependência e reciprocidade de interesse que existem entre espécies, verificamos que, efetivamente, a natureza é perfeita, obra digna do maior artífice, energia vital e criadora, que respeitamos e acatamos como Deus Supremo.

Adaptar-se à natureza, gozá-la, auscultando-a e pesquisando seus segredos, é tornar-se feliz. Os seus aspectos são vários, várias as suas condições e, de acordo com eles, devem ser o nosso vestuário, alimentação e vivendas; conforme estes a nossa arte decorativa. (HoEHNE,1930, p. 26)

Desse modo, o sentido de harmonia estética deveria estar presente em todas as realizações humanas, proporcionando um padrão de equilíbrio com as produções da natureza:

Entre o estilo das nossas casas, jardins e parques e a natureza local, deve existir perfeita harmonia, tanto no aspecto como na feitura e no colorido geral.

A natureza de uma região é constituída pela topografia do terreno, sua cobertura vegetal de bosques, florestas ou campos naturais, mares, rios, lagos, correntes atmosféricas, desencadeamento dos hidrometeoros, 
brilho do sol, animais e espécies vegetais, por tudo, enfim, que nela aparece. E, como esses elementos se entrelaçam e combinam, também nós precisamos adaptar-nos e harmonizar-nos com o todo, para vencermos na luta pela vida e para gozá-la como merece ser gozada. (HoEHNe,1930, p. 27-28)

O espírito romântico de Hoehne fazia dele um bom observador da diversidade e das especificidades locais. No caso do Brasil, a adaptação a um meio pródigo não devia ser sofrível, embora fosse fundamental levar em conta o fato de vivermos em terra de fisionomias múltiplas:

A fitofisionomia da nossa terra não é a mesma em todas as zonas, nem em todas as altitudes. Como em outras partes do mundo, ela varia de conformidade com as influências telúricas e atmosféricas. E, de acordo com o aspecto, a densidade e altura da vegetação, variam as espécies componentes da flora e as espécies que representam a fauna.

Idênticas não podem também ser as casas e as cidades em todo o nosso território, se querem harmonizar-se com a natureza adjacente. Elas têm de variar de conformidade com a natureza, porque a desarmonia de um conjunto se tornará feio, ridículo e se presta pouco para proporcionar bem-estar. (HoEHNE, 1930, p. 28)

Segundo Hoehne, a natureza devia ser a mestra e inspiradora de todas as criações, sobretudo no Brasil, pois

nenhum outro país do mundo tem maior variedade de motivos do que o nosso. As nossas florestas e campos naturais ostentam trepadeiras e ervas com flores mais bonitas e mais belas do que as do Acanto da Grécia e abrigam orquidáceas com flores mais lindas e artísticas do que todas as rosas da Bulgária e Itália [...]

É urgente e muito conveniente que volvamos as nossas vistas para todas essas maravilhas da natureza indígena para utilizá-las nas artes, nos jardins, nos parques e nos salões. Assim fazendo, praticaremos obra patriótica, porque concorreremos para que a gente da nossa terra aprenda a apreciá-la, a amá-la, não só pelo que ela produz do lado intelectual, mas também pelo que nasce e brota espontaneamente do seu ubérrimo solo. (Hoenne, 1930, p. 33-34)

Essa era a perspectiva de Hoehne. Ele sempre teve uma preocupação com a exploração dos recursos naturais, o que dá à sua obra um tom de objetividade e pragmatismo, embora o fundamento fosse uma percepção estética do mundo natural, na qual os humanos eram parte da totalidade, e 
cada uma das outras partes, todas inter-relacionadas, valia por si própria e por ser parte do todo.

Acompanhemos, portanto, a excursão imaginária sugerida por Hoehne.

Partindo de São Paulo, onde as florestas que outrora haviam emoldurado os rios:

[...] Pinheiros e Tietê foram riquíssimas de orquidáceas. Toda a vargem ocupada agora pelo Braz, Mooca e Belém, como Casa Verde, Anastácio, Butantã e Pinheiros, até Santo Amaro, ostentou matas mistas de preciosas espécies lenhosas e nos terrenos mais secos erguiam-se "Pinheiros" inumeráveis, que justificavam o codinome "Curitiba" que o aborígine dava a esta e toda a região planaltina do Paraná e Santa Catarina. (HoEHne, 1949, p. 53)

No entanto, onde há três séculos sorriam as belíssimas florestas, crescia agora a cidade com as suas chaminés e o tráfego intenso de viaturas a transportar os produtos da indústria. Entrando por uma das matas sobreviventes até chegar a uma região de vegetação campestre, as orquidáceas eram abundantes. De acordo com as localidades, variavam as espécies, as formas e os tamanhos, as cores e os perfumes. Ao deixar o planalto rumo à Serra do Mar, chegava-se em primeiro lugar aos campos de altitude, mais adiante aos caapões de mata fechada, até encontrar os caminhos traçados por entre as árvores, cipós e arbustos, que serpenteiam encosta abaixo:

O ambiente, em que agora nos encontramos, é de floresta tipicamente higrófila. São árvores pouco elevadas, com raízes pouco profundas e grande carga de epífitas entre musgos e hepáticas. Temos a impressão de nos encontrarmos num relicário da natureza, porque o bípede humano dendroclasta ainda não exerceu aqui a sua nefasta atividade destruidora. O lugar em que nos encontramos está sob a guarda do Instituto de Botânica e é religiosamente guardado e conservado inalterado desde 1909, quando o cientista Professor Dr. Herman Von Ihering aqui estabeleceu o início de uma Estação Biológica, para ser isto que hoje é: um relicário da natureza, onde esta domina, o homem apenas ingressa como observador e sem licença de retirar nem de colocar qualquer planta ou animal. (HoEHNE, 1949, p. 57)

Tratava-se da Estação Biológica do Alto da Serra da Paranapiacaba, uma das primeiras áreas ambientalmente protegidas no Brasil, sempre 
referida por Hoehne como modelo de área de proteção à natureza. Orgulhava-se ele pelo número de cientistas que a visitavam e pelas possibilidades de pesquisa oferecidas em um ponto de tão fácil acesso a partir de São Paulo. A Estação era

[...] um precioso documento biológico-histórico que encerra as nascentes do Rio Grande e tributários do Cubatão. Tudo o que nela existe conservase religiosamente intacto. As picadas permitem aos visitantes percorrêla em todos os sentidos, mas não lhe tiram nada da sua composição e vetustez. Caindo uma árvore através de uma delas, corta-se o pedaço que impede a passagem e deixa-se ficar o restante como o acidente a arrojou, para que a natureza reconstrua, cubra e desfaça o que os meteoros ocasionaram. O jardineiro e mestre ali é a natureza, o homem apenas é guarda, observador e aluno. (НовнNE, 1937, p. 77-78)

Ali se podia estudar o equilíbrio em que viviam inumeráveis espécies de animais e vegetais:

Neste reduto, religiosamente guardado, conservam-se em plena liberdade e nas condições em que se formaram, centenas de espécies que, sem exceção, denunciam afinidade ecológica. Todas elas são aptas a absorver e a eliminar rapidamente grandes quantidades de líquido. Abundando a umidade na atmosfera, elas a absorvem; secando o ar, se encarquilham, porque depressa eliminam a água que armazenaram. Voltando as brumas ou chuvas, em uma hora voltam ao natural e apresentam-se com o mesmo viço e pujança anteriores. Os períodos de seca são limitados e nunca duram o suficiente para deixar a camada de humo e os detritos totalmente secos. (HoEHNE, 1937, p. 81)

Eram condições ótimas para a reprodução da diversidade da vida, um santuário onde

tudo transpira confiança, tudo está no mais completo sossego e paz. Não penetram ali os depredadores, os apreciadores de plantas e animais arrancados do seu ambiente. Têm acesso os verdadeiros amigos da natureza, os que se deleitam em estudar a ecologia e mútua dependência dos seres, os que apreciam a natureza assim como ela é sem a intromissão do homem. (HOEHNE, 1937, p. 81-82)

Lugar de idílio e pesquisa: era como Hoehne entendia que deviam ser as áreas de reserva do patrimônio natural, mantendo algo da paisagem que não havia sido criada pelos humanos. ${ }^{1}$ 
Continuemos a descer a serra. A floresta variava no seu porte e no seu aspecto, conforme a maior ou menor altitude do terreno. À proporção que se descia, as árvores tornavam-se, gradativamente, mais altas. Em algum momento, o nevoeiro tomava conta da paisagem, que se tornava sombria, restando sentar e auscultar a natureza, observar como ela responde às influências do clima e às suas mudanças bruscas. Os animais e as plantas ocultavam-se, o horizonte visual se reduzia a menos de três metros, aguardando-se por mais de uma hora até que o sol retornasse e começasse a secar e colorir de novo o ambiente: "Vivemos algumas horas ao contato e sob a impressão da natureza, auscultamos e sentimos, todavia não a compreendemos, apenas percebemos seus efeitos" (HoEHNE, 1949, p. 58).

Ao observador arguto não escapavam os imperativos que promoviam, nem as razões que justificavam a diversidade. Ele estudava as mudanças bruscas do clima e os demais fatores ecológicos, embora permanecesse algo de inefável na natureza, aqui tão diversa.

Caminhando-se nessas matas higrófilas das cristas da Serra do Mar e dos seus ramais, desde o sul de Santa Catarina até ao Espírito Santo, encontram-se sempre ambientes semelhantes, mas espécies diferentes. Sem receio de errar, poderemos assegurar que foi exatamente nesta admirável Serra que a natureza mais se esmerou em produzir Orquidáceas, Bromeliáceas, Aráceas, Melastomáceas, Pteridófitas e musgos em geral, para habitarem sobre as árvores e atapetarem as rochas, relativamente raras, que aqui e acolá emergem como maciços da vestimenta arborescente. (HoEHNE, 1949, p. 60)

A menos de cem metros de altura sobre o nível do mar, o terreno ainda era levemente acidentado, recortado por ribeirões, córregos e rios, o calor aumentava e os mosquitos zumbiam, o solo era recoberto de extensa ramaria, abundavam as palmeiras, especialmente as juçaras. Já ao nível do mar, Hoehne relata:

Chegamos, enfim, a um triste tugúrio de pescador. A canoa, amarrada às raízes de uma árvore, no-lo denunciou e o ladrar de um cãozinho de costelas protuberantes, fez aparecer o homem que manifesta espanto, ao ver-nos vir dos lados da serra. Os arredores da sua mísera habitação, num raio de 20-30 metros, estão limpos. Mas árvores remanescem a fim de formarem ambiente sombrio. Entre elas estão estendidas redes e tarrafas, utensílios do pescador. Ele, o dono desses materiais, acocora-se diante de nós, começa a picar o fumo com sua faca, enquanto conosco 
conversa. Informado de onde vimos, levanta-se mais confiante e pergunta: Não querem ir até a praia com a canoa? (HoEHNE, 1949, p. 63)

No trajeto até a praia, havia orquídeas e outras belezas naturais que encantavam Hoehne, observador atento da sensibilidade e do conhecimento do pescador, homem que vivia em meio à natureza e a nomeava, certamente com nomes diferentes daqueles da ciência. Nova parada e o canoeiro despedia-se, indicando o trilho por entre as dunas até o mar. A expedição seguia rumo ao sul, atravessando matas e nhandus ralos e mais densos, até chegar ao rio Juquiá, e por este, até a confluência do Ribeira de Iguape. Ali Hoehne registra os sinais de devastação florestal. Na altura de Xiririca, "os vapores fluviais [...] são sorvedores de lenha e a exploração das matas é aí a principal ocupação dos sitiantes aos quais os mesmos vapores servem, fornecendo-lhes artigos para o seu indumento e alimentação" (HоEHNE, 1949, p. 65-66).

Apesar disso, ali onde a mata se adensava, eram numerosas as espécies de orquidáceas, entre muitas outras plantas. Seguindo até a cidade histórica de Iguape, e de lá até as ilhas Comprida e do Cardoso, alcançava-se a baía que se estende além de Cananéia. O cenário se transformava, a praia e as matas ralas ofereciam oportunidade para que se observassem outras variedades de orquídeas. Era o que se fazia durante o cruzamento do varadouro para Guaraqueçaba e a viagem marítima até Paranaguá:

Chegados a Paranaguá, encontramo-nos num novo campo ecológico. Nova reentrância da serra assinala-se aqui, onde o rio São João, antigo Cubatão, tem o seu estuário, formado por uma baía. Sigamos, todavia, primeiramente, para a Praia de Leste. Para isso dispomos de excelente estrada de rodagem que, em grande parte, é pavimentada com materiais de sambaquis. Assim, contribuem os antiqüíssimos malacófagos, que reuniram essas montanhas ou pirâmides de conchas, ostras, e outros elementos marinhos, para o conforto da geração atual. É evidente, todavia, que a futura, talvez, censure esta acerbamente por esse uso do material, o que, para as remotas eras, seria considerado ato de inominável vandalismo. (HOEHNE, 1949, p. 67)

Sempre comentando a diversidade de orquidáceas e a fitogeografia de um modo geral, Hoehne agora conduzia a excursão rumo ao planalto, pela Serra da Graciosa. Os comentários sobre o aspecto da natureza, sobre a harmonia alcançada pelo engenho humano ao recortar a paisagem, sobre a construção da estrada de ferro que conduzia até o porto de Paranaguá, 
mostram claramente a sua aprovação das possibilidades de um progresso alcançado com base no respeito e na apreciação estética do mundo natural:

Tudo que se encontra nesta região do nosso país representa honra para a engenharia nacional. Todavia, existem muitos brasileiros que preferem visitar a Europa e desconhecer essa maravilha da engenharia indígena [...] O espetáculo que se observa, ao viajar nesse trecho de estrada de ferro, fica gravado indelevelmente na retentiva. Aqueles abismos hiantes, com suas catadupas maravilhosas, das quais brumas sobem incessantemente como fumos de holocaustos oferecidos ao Criador, são ambientes em que a flora rapidamente se restaura. Por isso os melhoramentos referidos, longe de lhe aduzirem prejuizo, lhe proporcionaram vantagens, permitindo ao homem admirar tão belos cenários da janela do carro da estrada de ferro ou do seu automóvel. (HoEHNE, 1949, p. 68)

Maravilhado com a paisagem e com a riqueza de espécies da flora na seção paraneanse da Serra do Mar, Hoehne sugeriu, quando de suas viagens à Curitiba e Santa Catarina, nos anos de 1928 e 1929, que ali fosse criada uma estação biológica:

Nas rochas e nas árvores podemos ver orquidáceas de centenares de espécies, todas, porém, de flores pequenas e de maior interesse botânico do que comercial. Pretender descrever a flora orquidológica desta região zomba de toda veleidade literária. Nós, depois de Saint-Hilaire, Frederico von Sellow e outros, já o tentamos, mas ficamos muito aquém do que de fato aquilo representa, como viveiro ideal de todas as dendrícolas. (HoEHNE, 1949, p. 68)

Sem demora, descíamos a serra, agora em direção a Florianópolis, passando antes, por Tijucas, Jataí e Joinville. A região era riquíssima em bromeliáceas e orquidáceas. Especialmente,

Florianópolis é [...] um jardim de orquidáceas. Assim o são ainda muitas ilhas menores que se agrupam em seu redor e que emergem, mais distantes no oceano, como montes verdes. Algumas destas [...] constituem-se refúgios destas epífitas e deveriam ser mantidas como relicários e guardadas como estações ecológicas invioláveis [...]. (HoEHnE, 1949, p. 68)

Por diversas vezes, Hoehne propunha em seu textos a criação de estações biológicas, com a finalidade de proteger os ambientes naturais, sobretudo aqueles dotados de uma diversidade maior de espécies. Havia a neces- 
sidade, porém, de que os setores da sociedade interessados se organizassem para pressionar os governos a assumirem uma posição firme em defesa da natureza.

De volta ao continente, a expedição seguia até Laguna. No trajeto, Hoehne refletia sobre o que teriam dito Auguste de Saint-Hilaire e Frederick Sellow, naturalistas que conheceram e estudaram essas regiões no começo do século XIX:

[...] se eventualmente ali nos encontrassem agora a procurar exemplares de Orquidáceas? Sem dúvida nos relatariam que as viram em profusão, não apenas na Ilha de Florianópolis, mas em toda essa zona litorânea de lá até a fronteira e todo o nordeste do Rio Grande do Sul. Contar-nosiam que as encontraram em milhões de exemplares, cobrindo vetustas árvores de que já não restam sinais, que as viram sobre rochas que hoje estão limpas. Todavia, deve admirar-nos que, após um século e meio, ainda consigamos encontrar tantas Orquidáceas nessa riquíssima região do Brasil, na qual, desde aqueles tempos e até ao presente, a sua extração e exportação têm sido exercidas por dezenas de pessoas, numa proporção assustadora. (HoEHNe, 1949, p. 74)

Era de se perguntar, segundo Hoehne, se, decorrido mais um século, ainda seria possível, ao eventual leitor da narrativa, deparar com as mesmas espécies de orquídeas.

Deixávamos, então, a Serra do Mar e a região que entre o seu sopé e a praia se estendia pelo litoral, depois de constatada a fantástica riqueza florística que ali se reproduzia. De volta ao planalto, surgiam as matas de araucária, imbuia e erva-mate. Hoehne observava que a flora orquidológica dessa região fora estudada por diversos autores, entre os quais, Pér Dusen, que ali fixou moradia por vários anos, e Saint-Hilaire, que classificoù o local

[...] como "Paraíso do Naturalista". Ele começa em Itararé e estendese para além das fronteiras do Rio Grande do Sul. Tão rico é de espécies terrestres de Orquidáceas, que somente nos gêneros Stenorrhynchus, Pelexia e Sauroglossum temos registrado mais de duas dezenas de espécies. Todas elas com raízes carnosas e fasciculadas, adaptadas aos incêndios que todos os anos percorrem essas lindas campinas, em que milhares de outras plantas espontam na primavera e mantêm toda a região como jardim florido até dezembro. (Hoenne, 1949, p. 77)

José L. de A. Franco; José A. Drummond. Frederico Carlos Hoehne: viagens e orquideas 
Especial atenção merecia Vila Velha, cujas formações rochosas especialmente moldadas pela natureza deveriam ser preservadas para as gerações futuras:

[...] que nunca teve habitantes e todavia impressiona como ruína de palácios e castelos da idade média. Tudo é trabalho das chuvas e do vento na rocha de arenito. É um grupo de rochas, assim esculpidas, de trinta metros de altura, com amuradas, ameias, escarpas e torreões, recortado de ruas estreitas e escuras, que se constituiu refúgio de dezenas de espécies de Orquidáceas, Bromeliáceas, Cactáceas e Líquen. São estes últimos que fornecem a coloração branco-acinzentada, que de maior distância impressiona como caliça destruída. Vetustas árvores formam um bosque numa extremidade e, nas angustas ruas, "Pinheiros" idosos igualam a sua plana copa com os patamares dos blocos transformados em jardins de Cactáceas globulares.

[...] Acreditamos que o atualmente existente é apenas uma pequena fração do que existiu há meio século. Por isso mesmo precisará ser defendido como relíquia da natureza. (HoEHNE, 1949, p. 76-77)²

O passeio prosseguia por meio de um avião imaginário que sobrevoava o Rio Grande do Sul. A maioria das espécies representadas era peculiar, também, aos estados do Paraná e Santa Catarina. O vôo atravessava os pampas e a região de aluvião da Argentina, passando pelo Uruguai e Paraguai, aterrissando em Porto Esperança, em Mato Grosso (atual Mato Grosso do Sul), em pleno Pantanal. A região não era especialmente propícia à existência de orquídeas, embora fosse possível encontrar pequena variedade delas, que surpreendiam pelo tamanho das flores. Seguindo até Corumbá, um pouco mais convidativa ao orquidófilo, e de lá até Cáceres, nos caapões e nos cerrados encontrava-se alguma variedade de orquídeas, um pouco menos nos campos limpos, o que levava Hoehne a concluir que: "Pretender-se, entretanto, afirmar que Mato-Grosso, que apresenta dois terços da sua superfície semelhante a esta, é região rica de Orquidáceas, é desconhecer o Brasil. Já dissemos que ele seja talvez o mais pobre destas plantas" (HoEHne, 1949, p. 80).

Rumo ao norte, seguimos até Tapirapoan, e de lá, até ao Chapadão dos Parecis:

Primeiramente e até pouco acima de Porto do Campo, continuaremos pelo curso do rio Paraguai; depois penetraremos no rio Sepotuba. Nas margens surgem as florestas em que abunda o "Auassú" - Orbgnya oleifera -, linda e altaneira palmeira, que representará fonte de renda 
considerável em futuro próximo. São exemplares de mais de 20 metros de altura que deixam farfalhar as suas pinadas frondes ao sopro da brisa. As árvores maiores raramente as alcançam, jamais as igualam em beleza, nem se comparam a elas pelos seus préstimos industriais. (HoEHNe, 1949, p. 81)

Hoehne, sempre atento aos aspectos estéticos e à descrição científica, não perdia de vista a maneira pela qual os humanos ocupavam, ou poderiam ocupar, as terras por que passava. Os recursos naturais disponíveis e as produções locais o interessavam:

Alcançamos Tapirapoan. Existe aqui uma velha fazenda que teve sua origem da indústria extrativa da "Poaia" e "Borracha". Esta provinda das matas mais afastadas, dos tributários superiores do rio Sepotuba e das contravertentes setentrionais que derramam no rio Verde e outros. Aquela das matas da encosta rumo do Guaporé. Hoje criam-se bovinos, suínos e asininos, cultivam-se milho e arroz, de que a Comissão Rondon era o seu principal freguês. (HoEHNE, 1949, p. 31)

À medida que a mata se tornava mais densa, em direção a Serra dos Parecis, surgiam maiores oportunidades para se observar a flora de Orquidáceas. Na subida da serra, as Bromeliáceas, Cactáceas, Aráceas e Eriocauláceas lhes faziam companhia:

Galgada a encosta, penetramos numa região de matagal raquítico de largura irregular, que constitui a transição da floresta para o campo limpo e árido que temos no planalto ou Chapadão dos Parecis. Nesse matagal deparamos com espécies de Epidendrum, Encyclia, Maxillaria, Octomeria, Plerothallis etc., todos tipos mais ou menos xerófitos [...]. (HoEHNE, 1949, p. 83-84)

O Chapadão dos Parecis e as pragas de gafanhotos que ali pareciam ter origem eram temas de preocupação para Hoehne. Em duas ocasiões havia tratado do assunto em seus artigos, ${ }^{3}$ de 1936 e 1946, descrevendo a fitogeografia da região, a superpopulação e a migração dos gafanhotos e os meios de combatê-los. Acreditava que, em primeiro lugar, deviam ser preservadas as florestas, e num segundo momento, as pragas deviam ser combatidas com a aplicação de veneno no próprio local de origem. No entanto, em terras tão áridas havia um outro aspecto a ser avaliado, afinal

se nos desertos da África e da Arábia os beduínos encontram alimento, esse deserto do nosso país proporciona também aos íncolas Parecis, aqui

José L. de A. Franco; José A. Drummond. Frederico Carlos Hoehne: viagens e orquídeas 
domiciliados, recursos para a sua subsistência. O próprio gafanhoto tornou-se para eles o camarão. Quando outra coisa não conseguem caçar, apanham-no em quantidade, assam-no na fogueira e comem-no acompanhado de castanhas de tucari, coquinhos e frutas que as escassas mangabeiras e mandapuçás lhes proporcionam, apesar de molestadas pelo gafanhoto. Os veados e outros animais tornaram-se raros, todavia o íncola consegue ainda surpreendê-los nas vazantes, várzeas e cabeceiras onde a pastagem surge no terreno alagadiço. (Hoenne, 1949, p. 84)

A viagem imaginária prosseguia, o Chapadão dos Parecis ficava para trás, enquanto terras mais prósperas de orquidáceas eram demandadas:

Atravessamos os rios: Papagaio, Buriti e Saueuiná e penetramos na região em que as matas ciliares, em muitos trechos, se comunicam entre si, formando florestas contínuas. Descemos para o vale do Juruena e o transpomos também, tendo vencido 45 léguas desde Aldeia Queimada. Estamos livres dos gafanhotos, em meio de matas e campos, que melhor nos impressionam. Juruena é região que merece a visita do orquidólogo. As águas do rio são cristalinas como as de outros que ficaram para trás, porque deslizam sobre fundo arenoso e não recebem as enxurradas, visto não haver ainda o homem tirado as matas ciliares que absorvem as águas pluviais que a elas afluem dos campos quando, eventualmente, sobram para tanto. Correntosas, clareiam também rapidamente se uma ou outra vez se tornam leitosas. São estes os rios que, com outros mais além, constituem as cabeceiras dos tributários do Tapajós. As matas que aqui temos são muito mais ricas de dendrícolas e orquidáceas terrestres abundam nas alvíssimas areias que existem junto aos matagais brejosos. Estes matagais são, todavia, os melhores repositórios das plantas que nos interessam. (HoEHNE, 1949, p. 85)

Já em plena floresta amazônica, na mata que ornamentava a pequena cachoeira do Juruena, era observada a presença das seringueiras, dos jataís e dos ingazeiros. O local, apesar da beleza natural, evocava a Hoehne episódios tristes de sua viagem na Comissão Rondon:

Em 1909 estivemos aí curtindo fome. Ao chegarmos, encontramos um contingente de 70 praças e oficiais e, após dois meses de permanência, tudo estava reduzido a poucos, que em maioria formados de novos advindos para substituição. O beribéri, resultante de extrema anemia, ceifou todos e com dificuldade nos retiramos com os dois camaradas doentes. Célebre tornou-se ainda aí um ataque ocorrido quinze dias depois que de lá havíamos saído. Os índios que estiveram ocultos e 
foragidos desde o dia da chegada do pessoal da Comissão Rondon, surgiram e atacaram o destacamento a flechadas, transformando um telegrafista em verdadeiro paliteiro, cravando nele 14 flechas. Todavia, nenhum dos feridos veio a falecer e com um disparo de carabina Mauser os silvícolas fugiram. (HoEHNe, 1949, p. 86)

Seguindo em direção aos saltos Utiariti e Belo, locais excelentes para a observação de orquídeas, Hoehne chama a atenção para a capacidade de geração de energia elétrica que esses saltos poderiam fornecer no futuro para a imensa e fértil região a jusante dos rios Utiariti e Sacre. Por entre campos cerrados, onde cresciam mangabeiras, mandapuçás, marmeladinha, tucaris e outras fruteiras que serviam de alimento para os índios Parecis, chegávamos, então, à Ponte de Pedra do Sacuruiná. De lá, com o propósito de conhecer a hiléia amazônica, povoada pelas castanheiras e seringueiras, regressávamos ao porto do Juruena, para prosseguir por ele até Comemoração de Floriano. Depois, deixando o rio e as misteriosas selvas, galgávamos uma suave encosta até o terreno rico em gramíneas e outras forrageiras, que o general Rondon denominou Campos Novos da Serra do Norte, destinando-os a se constituírem em um núcleo de recursos para a linha telegráfica que liga Mato Grosso ao Acre. Hoehne observava:

Arredios eram os íncolas da região quando ali estivemos em 1911. Em grupos surgiam, então, armados de cacetes, que eram pedaços de troncos e galhos quebrados de árvores, e impressionavam-nos pelo seu aspecto guerreiro e hostil. Gesticulando e falando língua que não entendíamos e mentindo-nos sempre, que de longe vinham, para despistar-nos, custaram eles a tornar-se susceptíveis da sinceridade que a Comissão Rondon por eles nutria. Em torno da fogueira crepitante assaram ali as suas presas de caça: gafanhotos, filhotes de araras, macacos, lagartos, cururus, cachorrinhos do mato etc., demonstrando-nos o seu enorme atraso, no que concerne a higiene e costumes. Com pelo e intestinos assavam essas iguarias e, espremendo ligeiramente as tripas, para libertá-las do seu conteúdo, comiam-nas, sendo que, dos filhotes de araras, nem mesmo o conteúdo era desprezado, por considerarem-no simplesmente polpa de "Buriti". O espetáculo tornava-se repugnante, mas também eles nos encaravam com desprezo quando nos viam ingerir comida salgada ou dormir em rede. Para poderem comer o feijão que lhes era oferecido, despejavam água no prato e, depois de o haverem lavado, ingeriam-no. Do mesmo modo repugnavam-lhes a carne salgada e outras comidas temperadas. Dos vegetais conheciam muitos e mesmo de algumas Orquidáceas nos disseram os nomes pelos quais as distinguiam. (HoEHNE, 1949, p. 88-89)

José L. de A. Franco; José A. Drummond. Frederico Carlos Hoehne: viagens e orquídeas 
Nessa breve tentativa de etnologia, Hoehne não escondia a sua repugnância pelos hábitos e costumes dos autóctones, que consideravam atrasados, embora não deixasse de reconhecer que as nossas práticas também eram por eles estranhadas, e que eles tinham um conhecimento legítimo do meio natural em que viviam.

De volta ao acampamento do Juruena, ele relembrava:

[...] em dois meses de ingentes esforços, com parcos recursos de ferramentas, construímos cinco canoas, em fins de 1911, para a realização da viagem de lá até São Manuel, no Estado do Pará, para de lá, até Santarém e Belém do Pará, continuarmos em vapor fluvial e, enfim, tornar ao Rio de Janeiro via marítima.

Arrastadas para o rio, foram as canoas levadas até ao porto do Juruena e nelas embarcamos para penetrar no até então desconhecido. Os perigos prenunciados: bugres, feras, cachoeiras e saltos, atormentaram o cérebro, mas revelaram-se menos desanimadores do que as nuvens de mosquitos brancos e a tormenta diuturna dos piuns e borrachudos. (HOEHNE, 1949, p. 89-90)

A despeito dos perigos, incômodos e peripécias da viagem, Hoehne considerava que, passados os anos, "aqui estamos realizando mentalmente o que em 1911-12 fizemos pessoalmente. Então dissemos e hoje repetimos: 'Todos os sofrimentos são olvidados quando recordações melhores existem' e estas existem de fato para nós" (HoEHNE, 1949, p. 91).

O prazer de observar e catalogar espécies, ou mesmo de percorrer espaços palmilhando a fitogeografia do país, compensava sacrifícios e riscos extremos. Hoehne recordava a passagem da corredeira, denominada Caldeirão do Inferno, como uma das experiências mais traumáticas de suas viagens:

[...] nessa corredeira citada, uma canoinha que saiu na frente para indicar o canal, de súbito desapareceu no turbilhão das águas encapeladà e o seu único tripulante emergiu vinte metros abaixo e agarrou-se a um tronco encalhado entre as rochas. Todavia, ainda não havia chegado ao lugar onde deveria indicar-nos o melhor caminho. Assim, as nossas canoas ao caldeirão chegaram, sem terem quem dos tripulantes conhecesse a situação real. Diante dos nossos olhos vimos, em dois segundos, a canoa na nossa frente girar em torno como uma folha que se atirasse a um funil com líquido em rotação, para, instantes depois, ser cuspida e sair aos saltos, como cabrito perseguido, sobre altas ondas do tremendo rebojo. Apenas isso presenciamos, já a nossa ali se achou na 
mesma posição, obrigando-nos a procurar equilíbrio para não sermos lançados fora. Inclinada a mais de $45^{\circ}$, ela revolteou algumas vezes com a proa no fundo do funil do rebojo e de súbito dali saiu, não de frente, mas de popa e só a Providência nos livrou de desastre fatal, nesse caldeirão do inferno. (HoEHne, 1949, p. 93)

Não era raro ocorrer a perda de tudo, inclusive da vida, em situações semelhantes. Os homens da região costumavam disparar as suas carabinas oferecendo sacrifício ao deus do penedo e súplicas eram erguidas à mãe d'água: estes eram os expedientes que acompanhavam o ritual, sempre incerto, da passagem das canoas pelas perigosas corredeiras. A vida na selva era pontuada por dificuldades, muitas vezes agravadas pela exploração dos homens que nela labutavam. Hoehne descrevia a faina do seringueiro, revelando a sua sensibilidade para a questão social:

Seringueiras enormes são entre si ligadas por estreitos trilhos que o seringueiro abriu para captar o látex dos seus troncos. Estes apresentam os vestígios da safra. Resultam as cicatrizes de cortes abertos a facão e em forma de espinhas ligadas a um sulco perpendicular no centro, que reúne o látex e o encaminha para o bicame de folha de Flandres ou zinco, espetado na extremidade inferior, sob o qual é ainda colocada a canequinha que apara o líquido. Diariamente percorre o seringueiro estas picadas, recolhendo no latão, que trás às costas, o látex alvíssimo e viscoso que depois defuma e transforma em "bolachas" de várias arrobas de peso, que os regatões vêm buscar em troca de quinquilharias e alimentos, por preços calculados exorbitantemente, para, nos mercados de Belém e Santarém, ou São Luiz, colocarem a borracha por preços três vezes mais elevados. Então, novos intermediários e despachantes de firmas exportadoras apuram lucros que elevam os preços originais ao décuplo. São especialmente cearenses que aqui vivem de fígado inflado, revesando as horas do seu labor cotidiano com os acessos de febre, comendo peixe e alguns mamíferos que apanham onde armam as barracas de folhas do "Indaiá" ou do "Anajá". A farinha é a puva, que recebem em baquités forrados com folhas de pacová. Com granulações tão grossas e duras, esta farinha requer, não somente dentes bons, mas estômago resistente, devido a sua grande acidez. (HoEHNE, 1949, p. 91-92)

A viagem imaginária era, então, retomada, passando por São Luiz (no Amazonas) e de lá até Manaus, sendo as regiōes do baixo rio Negro especialmente ricas em espécimes de orquidáceas. Descia o rio Amazonas até Santarém, chegando por fim à cidade de Belém do Pará, que, segundo Hoehne, era um local ideal para a orquicultura. No jardim botânico do 
Museu Goeldi, nas árvores dos parques e praças, a abundância de orquídeas comprovava isso. As condições ótimas do clima e a proximidade dos Estados Unidos, grande consumidor de flores, podiam ser aproveitadas para tornar a cidade e mesmo as localidades próximas em centros de orquicultura.

A expedição prosseguia via Nordeste, acompanhando o litoral, realizando aqui e acolá pequenas incursões, a fim de reconhecer algo da flora orquidológica. Hoehne propunha:

[...] primeiramente fixemos nossa atenção no fato de que correm versões contraditórias a respeito dessa zona. Desde os tempos do Império até ao presente momento, têm sido ali despendidos capitais incalculáveis para dirimir o flagelo sinistro que se traduz pelas secas periódicas resultantes de fatores climatéricos dependentes dos ciclones atmosféricos [...] Tudo que nos preocupa agora é mostrar que, mesmo nessa adversidade, a flora tem produzido aí dendrícolas e terrestres que se filiam à família que vimos estudando e comentando. (HoEHNE, 1949, p. 95)

Hoehne evitava entrar nos já polêmicos aspectos políticos relacionados à seca no Nordeste. No que diz respeito à botânica, Alberto Loefgren era ainda considerado uma autoridade e a referência aos laços de amizade com ele indicava a influência que tinha sobre as concepções de proteção à natureza de Hoehne. Todavia, nas matas serranas do interior do Ceará, Pernambuco e Piauí, ainda se podiam encontrar várias e preciosas espécies de orquidáceas, que

[...] em milhões de exemplares devem ter sido extraídas e destruídas nos incêndios desde que o europeu advindo aí se estabeleceu, mas continuam subsistindo, como temos provas nas partidas que as firmas exportadoras de Pernambuco, anualmente, mandam para o sul do Brasil, para os Estados Unidos da América e para a Europa. O restabelecimento dos estoques naturais de fato se verifica, mas é evidente que o desnudamento do solo e a construção das vias de comunicações constituem fatores que decretam o total desaparecimento dessas lindas plantas dessa região do nosso país. (HOEHNE, 1949, p. 95)

Mesmo nas caatingas havia condições para a existência dos vegetais. Como o umbu e as várias espécies de cactáceas, algumas variedades de orquídeas desenvolveram mecanismos especiais de sobrevivência: pseudobulbos mais grossos, raízes fasciculadas, ou tuberas carnosas. Os humanos, que migravam quando premidos pela falta de água e alimentos na época da seca, retornavam quando das chuvas, para cultivar o solo, capaz de 
proporcionar o suficiente para o abastecimento nos períodos menos favoráveis. Hoehne acreditava, portanto, que, resolvido o problema das secas, a região seria tão habitável quanto o Sul.

Nas margens do rio São Francisco, especialmente próximo à cachoeira de Paulo Afonso, embora já bastante devastada a flora nativa às margens do rio, alguns redutos ofereciam espetáculos ímpares. Os coqueirais que se espalhavam do Maranhão à Bahia justificavam o nome de Pindorama dado pelos povos indígenas a essa região do país. No litoral sul da Bahia, às margens do Jequitinhonha, e nas vizinhanças do Espírito Santo, adensadas as florestas, reproduziam-se em profusão as orquídeas do gênero Cattleya $e$ Laelia.

No Estado do Espírito Santo, Hoehne chamava a atenção para que, no rio Doce,

[...] em seu vale pleno de florestas milenárias, a flora orquidológica constituiu-se atração para todos os orquicultores. Praticamente a configuração e topografia do terreno [...] formam as condições para flora tão variada e tão portentosa como encontramos aí. Infelizmente, como em outras partes do nosso País, o machado e o fogo destroem as selvas e assim ficam as Orquidáceas privadas dos ambientes necessários para a sua perpetuação e multiplicação específica. (HoEHNE, 1949, p. 97)

Em cada região visitada, Hoehne demonstrava a sua intensa preocupação com as devastações promovidas pelo machado e pelo fogo. Ele acreditava que a admiração pelas orquidáceas poderia contribuir para despertar o interesse e o respeito pela flora do país, ajudando a proteger natureza. No volume II de As plantas ornamentaes da flora brasílica, ao discorrer sobre as orquidáceas, explicava:

Sua vida misteriosa, como as suas flores cativantes, são coisas que atraem, deleitam e instruem, porque, cultivando-as, e examinado a sua estrutura, se colhem proveitos espirituais e se aprende a amar a obra divina que é a natureza, e, chegada a este ponto, a pessoa não sente mais inclinação para distrações indignas, não mais sofre com o tédio, porque sempre terá muito com que se ocupar, muito com que se distrair e instruir. (HoEHNe, 1936, p. 233-234)

Hoehne esperava que, convertida em passatempo, a observação e o cultivo das orquidáceas viessem a despertar o amor pela natureza nativa e, com isso, o sentimento de patriotismo, que ele acreditava ser necessário 
para a existência de uma relação mais previdente e harmoniosa do homem com o meio natural e seus recursos. Alertava:

Numa terra em que as leis e códigos florestais só existem no papel para inglês ver, muito cuidado precisa, portanto, ter o proprietário de florestas, quando quer conservar, para patrimônio do país, estas belas plantas que a natureza nos distribuiu. As matas virgens, em toda e qualquer localidade do nosso país, deveriam ser poupadas, se não fosse para mais nada, ao menos para conservar-nos as espécies que as compõem e para com elas proporcionar-nos os meios para estudos futuros da biologia do nosso país. Cuidar destas coisas não é apenas dever dos governos; é, pelo contrário, dever e privilégio de quantos amam e queiram o engrandecimento do nosso amado Brasil. (HoEHNE, 1936, p. 251-252)

Poucos anos depois de entrar em vigor uma vasta legislação - Código Florestal, Código de Águas, Código de Caça e Pesca etc. — referente à proteção da natureza, Hoehne registrava a dificuldade de torná-la eficaz. Segundo ele, isso indicava a necessidade de que a sociedade se conscientizasse dos efeitos danosos da devastação do patrimônio natural, representado pela flora e fauna, para que este pudesse, de fato, ser conservado:

[...] quem não possui matas para proteger e salvaguardar para os pósteros, deve estimular aqueles que as possuem e procurar aproveitar das condenadas ao extermínio tudo o que possa ser conservado pela cultura. As nossas Orquidáceas, especialmente, estão neste número. Elas podem ser cultivadas facilmente e cultivando-as com carinho e atenção, aprender-se-á a estimá-las cada vez mais. A estimação aduzirá também o respeito e provocará a defesa de tudo o que a nossa natureza produz. (HoeHne, 1949, p. 252)

Desse modo, Hoehne acreditava que o conhecimento das orquidáceas e dos diversos meios onde elas medravam despertaria o interesse dos brasileiros pela proteção da natureza. Esperava que os cultivadores percebessem a necessidade de habitats variados para manter a diversidade de orquídeas existentes no país. Quem desejasse cultivar essas plantas necessitava

não só começar devagar para ganhar experiência, mas também observar muito para não ter desgostos e prejuízos. A própria natureza deve, sempre que possível, ser a sua mestra, porque, observando o ambiente e as condições em que as diferentes espécies vivem, se aprende a cultivá-las com sucesso. (HoeHne, 1936, p. 252) 
Aqui Hoehne abordava a questão tão atual das diferenças e das relações entre a preservação in situ e ex-situ, ensinando que a segunda não prescinde da primeira.

Norteava os trabalhos de Hoehne uma preocupação com o aproveitamento racional dos recursos naturais, para o qual deviam contribuir o conhecimento científico, o sentido de apreciação estética e a consideração dos interesses das gerações futuras. No texto da Iconografia das Orchidáceas do Brasil, ele trata com detalhes dos problemas relacionados com a exploração econômica dessas plantas. Antes de abordá-los, porém, acompanhemos a excursão mental até o seu ponto de chegada.

Prosseguindo em direção ao sul, pelo litoral, o Espírito Santo ficava para trás. No Rio de Janeiro, Cabo Frio, devido ao seu avanço em direção ao oceano, constituía-se em região excelente para as orquidáceas. $\mathrm{Na}$ verdade, toda a região entre o litoral e a Serra do Mar era especialmente pródiga dessas plantas: o percurso incluía os picos da Floresta da Tijuca, as serras da Estrela, em Teresópolis, e a dos Órgãos, já em direção a Petrópolis, Mangaratiba, Angra dos Reis e Parati, e então, galgando a Serra da Bocaina em direção ao vale do rio Paraíba do Sul, Barra Mansa, Resende e São José do Barreiro. Hoehne entendia que

a Serra do Mar proporciona excelentes motivos ao botânico, mas o artista pintor, como o fotógrafo amador, encontra nela igualmente muito assunto digno de sua atenção. Em cada recôncavo, as paisagens são diferentes $\mathrm{e}$ em cada altitude outras as espécies vegetais que constituem o sub-bosque e a flora epífita. As terras são, entretanto, más, por serem frias e pouco profunda a camada permeável. Sem prejuízo para a agricultura e a pecuária, as florestas existentes nessas encostas poderiam ser conservadas para perpétua documentação da flora e fauna desta região austro-oriental do nosso país. (HOEHNE, 1949, p. 100-101)

No vale do rio Paraíba do Sul, Hoehne constatava que as superfícies que outrora haviam sido cafezais, roças e pomares, deixadas por longo tempo como "taperas imprestáveis", agora estavam sendo reaproveitadas. Ele especulava que o "larguíssimo vale" poderia,

[...] em futuro próximo, proporcionar campos de cultura para cereais e frutas. Torna-se necessário, entretanto, que se introduzam processos agrícolas modernos, liquide com as formigas e acabe com os pessimistas, que falam em terras cansadas, quando procuram ocultar a verdadeira causa dos seus insucessos no trabalho. Haja vista o que realizaram nessa zona os trapistas com a cultura do arroz. (HoEHNE, 1949, p. 102)

José L. de A. Franco; José A. Drummond. Frederico Carlos Hoehne: viagens e orquídeas 
Transposto o vale, encontrava-se a Serra da Mantiqueira, onde eram visitadas Campos do Jordão, estação climatérica afamada pela pureza do seu ar rico em ozônio, e Itatiaia, sede do primeiro parque nacional brasileiro. Ambas as localidades apresentavam uma flora rica e que variava com a altitude do terreno, ora coberto de florestas, ora predominando os campos de altitude, sempre incluindo as orquidáceas. Seguindo adiante, via Resende, a expedição demandava o interior de Minas Gerais. Hoehne observava, com relação às regiões serranas, que

sempre que nos encontramos nessas serras maravilhosas, recordamonos das impressões que elas deixaram aos naturalistas estrangeiros: SaintHilaire, Frederico Sellow, Carlos Frederico Philipe Von Martius, Johann Pohl, Schwacke, Riedel, e ainda aos botânicos nacionais: Barbosa Rodrigues, Álvaro Astolpho da Silveira, Leônidas Damazio e outros. Desde moço tivemos também uma inclinação toda especial para galgar e explorar as rochosas serras de Minas Gerais, que elevam a gente acima das tristezas dos vales, numa atmosfera límpida e rica de oxigênio [...]. (HoEHNE, 1949, p. 104)

Por entre os cerrados, matas ciliares e capões da região, a expedição galgava as montanhas ricas de minérios, férteis de orquídeas e outras plantas dignas de serem admiradas e estudadas. Lavras, Velozia, Barbacena, as montanhas ao redor de Belo Horizonte e Vila Nova de Lima eram localidades que descortinavam ao pesquisador e admirador uma enorme variedade de espécies florísticas. Sobre amostras de orquidáceas tiradas a esmo, Hoehne comentava:

[...] devem bastar, entretanto, para dar-nos a primeira impressão de uma serra do Estado de Minas Gerais, que poderemos reputar rica de Orquidáceas e, todavia, fácil de visitar. Ela se ergue a poucos quilômetros da cidade de Belo Horizonte e foi, em parte, incluída no plano do Jardim Botânico local. Conservá-la toda, impedindo a retirada de plantas, deveria ser preocupação séria das autoridades governamentais de Minas. O Estado precisa pensar na instituição de reservas da natureza, e aqui está uma, que não deveria ser desprezada, para testemunhar da flora serrana. (HOEHNE, 1949, p. 106)

As matas do rio Marzagão, outrora ricas em espécies da vegetação nativa, e que haviam desaparecido sem deixar vestígios, cederam lugar à indústria elétrica, à construção de casas para operários e aos campos de agricultura. Eram um exemplo da necessidade de se estabelecerem áreas 
destinadas à preservação de representantes significativos da fauna e flora. Chegávamos a Lagoa Santa, local escolhido pelo naturalista sueco Wilhelm Lund para viver e realizar os seus estudos sobre os fósseis, a flora e a fauna, e também pelo seu compatriota Eugenio Warming, para a pesquisa que originou um livro pioneiro no campo da ecologia. ${ }^{4}$ Era outro exemplo da gradativa substituição, em poucas gerações, da flora nativa por outra adventícia, em conseqüência das derrubadas, queimadas e de um nascente processo de industrialização. Hoehne alertava para o fato de que o próprio Warming havia chamado a atenção para esses efeitos da devastação e para a possibilidade de que, em um futuro próximo, as diversas espécies, que foram pela primeira vez catalogadas ali, só pudessem ser vistas em museus ou em herbários. Um indicativo do que vinha ocorrendo era o de que

nem mesmo a famosa "Figueira" do Largo da Matriz, monumento que deveria recordar sempre o grande Lund, foi poupada. Suas folhas irreverentes, levadas às calhas da igreja local, deram origem à sua difamação e posterior sacrifício a machado e a traçador. Ostentava nos seus ramos uma coleção de Orquidáceas que foram sacrificadas com ela na fogueira formada com os seus restos mortais. (HoEHNE, 1949, p. 108)

Apesar do quadro nefasto causado pelas devastações, ainda era possível encontrar muitos campos e florestas na região. A viagem imaginária de Hoehne prosseguia constatando a variedade e a beleza da flora das serras mineiras: Cipó, Piedade, Caraça, Garimpo, Gongo Soco, Ouro Preto, OuroBranco, Itambé, Itabira, Pedra Branca, Treituba. Estudadas e admiradas por botânicos nacionais e estrangeiros, estavam elas longe de serem conhecidas e interpretadas ecologicamente em toda a sua diversidade, característica das diferentes altitudes e microclimas.

Assim são as serras rochosas dessas Minas Gerais, berço das idéias alevantadas, pátria de muitos botânicos ilustrados. Altaneiras erguemse; heterogêneas são na sua estrutura e variadas na sua flora. Elas abrigam minerais preciosos e o itabirito aflora em muitas delas, onde o manganês e o ferro não predominam. A flora, sempre sequiosa para revestir, crestada embora pelos raios solares, surge numa profusão de espécies que zomba de toda veleidade descritiva. (HoEHne, 1949, p. 111)

Na verdade, Hoehne não acreditava que a ciência fosse capaz de enquadrar completamente a natureza. Havia algo que transcendia as possibilidades da racionalidade pura, sendo objeto apenas da apreciação estética e 
da sensibilidade. Para compreender as diversas faces do mundo natural eram necessárias tanto a disposição para o trabalho de observar, medir e comparar, quanto a atitude pacífica de contemplar desinteressadamente aquilo que se oferecia aos sentidos.

Descendo as serras, as matas ciliares abrigavam inúmeras espécies de orquidáceas:

As florestas são pujantes onde o terreno é de aluvião. Em algumas delas podemos andar sem maiores dificuldades, mas em outras, especialmente naquelas em que as madeiras já foram exploradas, como nas secundárias, dificilmente se consegue penetrar sem o constante uso do facão ou da foice. Nas primeiras deparamos com gigantescos Jequitibás, em cujos ramos se assentam belos exemplares de Cattleya labiata Warnerii e outras espécies do mesmo gênero, bem como Oncidium crispum e, aqui e acolá, O. phymatochylum. Nas árvores menores encontramos Cattleya porphyroglossa que, pelo seu porte, representa uma transição entre $C$. bicolor e C. granulosa [...]

Muitas espécies de flores pequenas existem tanto nas árvores menores como nas mais altaneiras [...]. (HoEHNE, 1949, p. 115-116)

A expedição encaminhava-se agora:

[...] para conhecer um pouco da região de Goiás onde o rio Araguaia e seus formadores constituem o mais importante acidente hidrográfico em meio dos intérminos cerrados e campos naturais, igualmente banhados pelo rio Tocantins e seus numerosos contribuintes. $\mathrm{O}$ aspecto é semelhante ao de Mato Grosso na mesma latitude. Célebres são, todavia, as florestas de São Patrício, que - segundo nos informaram -, vêm sendo impiedosamente destruídas pelos criadores de suínos, que tombam as árvores com o único objetivo de lhes deitar fogo para a obtenção de terras virgens para plantação de milho durante dois a quatro anos e ulterior abandono e novo avanço do machado e do facho incendiário. (HoEHNE, 1949, p. 116)

Hoehne reconhecia a riqueza e variedade da flora do de Goiás e apontava Ernesto Ule como o botânico que mais contribuíra para o seu conhecimento. Nos cerrados, cerradões e matas ciliares, havia uma diversidade de espécies de orquidáceas que merecia a atenção do estudioso e do admirador. No entanto, aqui também a sanha do machado e do tição fazia os seus estragos. Ao retornar pelos cerradões do ocidente de São Paulo, o mesmo quadro triste se apresentava: 
As matas secas, que são abatidas a granel, sem se nutrir interesse para o aproveitamento das preciosas madeiras ou da lenha, com o único objetivo de conseguir terras para semear capim Jaraguá, para formação de pastos para engorda de gado vacum. Preciosas madeiras, tais como "Sebastião de Arruda", "Aroeira", "Aderno", "Cabriúva", "Jacarandá Preto" etc., são destruídas lentamente pelo fogo, com o recurso da repetição dos incêndios durante dois e três anos após a primeira queimada, porque o transporte não corresponde aos preços que elas poderiam alcançar nas praças de São Paulo ou do Rio de Janeiro. (HoEHnE, 1949, p. 116)

Ainda em São Paulo, na altura do paralelo $22^{\circ}$, em direção ao leste:

Toda esta zona está praticamente desnudada. As matas virgens são raríssimas e as secundárias constituídas principalmente de "Eucalipto", que fornece excelente lenha, madeira para postes, estacas e dormentes, quando bem velho, mas nunca ambiente para a proliferação das plantas que nesse trabalho nos interessam. (HoEHNE, 1949, p. 116)

Já nas remanescentes matas de encosta de São João da Boa Vista, podiam ser encontradas orquídeas em profusão. De lá, a excursão retornava a Minas Gerais, passando por Poços de Caldas e pela pequenina Caldas, onde viveu e clinicou o sueco André Regnell, amante e estudioso da botânica local. Via Serra da Mantiqueira, passando ainda por Tiradentes, São João d'El-Rei e Juiz de Fora (seu local de nascimento), Hoehne retornava ao ponto de origem.

Ele justificava, então, os motivos da viagem, usando uma frase que se tornou lugar comum entre os ambientalistas modernos - "Ninguém pode defender aquilo que não conhece".

Ninguém nos censure, portanto, por havermos revelado o habitat de muitas Orquidáceas. Ninguém pode defender aquilo que não conhece. Aos proprietários das florestas, e governadores dos municípios e dos Estados, indicamos o patrimônio que lhes está confiado. Envidem, portanto, todos os meios, empreguem todas as forças e artigos de leis, a fim de conseguir estabelecer reservas florestais e estações biológicas, onde forem viáveis e recomendáveis, para que protegidas sejam e constituam testemunhas vivas daquilo que acabamos de referir.

Não olvidemos jamais que o Brasil é nosso e a mais ninguém assiste o dever de defendê-lo das garras, não só dos estrangeiros mas dos filhos desnaturados e impatriotas, que não trepidam em dilapidá-lo nem em explorá-lo no interesse pessoal. (HoeHNE, 1949, p. 124)

José L. de A. Franco; José A. Drummond. Frederico Carlos Hoehne: viagens e orquídeas 
A flora brasileira era extremamente diversificada e sugeria que outros tipos de plantas poderiam servir como tema de outras tantas "excursões mentais":

Do mesmo modo como acabamos de realizar esta excursão mental pelo nosso grande e belo país para conhecermos a sua riqueza orquidológica, poderíamos levar a efeito outras para estudarmos as suas Filicíneas ou "Samambaias", ou ainda para conhecermos as suas Bromeliáceas, Gramíneas, Begônias, Bignoniáceas, Apocináceas, Gencianáceas etc. Sempre teríamos ensejos para nos orgulharmos da nossa pujante e bela flora. Mas, se nos dedicássemos uma vez, devotadamente, ao estudo das árvores das nossas selvas virgens, que são os suportes naturais da maioria das mais preciosas Orquidáceas do Brasil, certamente descobriríamos que também elas são dignos ornatos da nossa flora que, do mesmo modo, deveriam merecer a nossa proteção, não somente pelo lenho ou madeira que proporcionam, mas pelas suas lindas flores. Uma coleção de árvores com flores vistosas ou abundante poderá proporcionar ao amigo da natureza tanto deleite quanto lhe proporcionam as Orquidáceas e estas se aninhariam espontaneamente sobre muitas delas. (HoEHNE, 1949, p. 124)

As orquídeas faziam parte de um sistema equilibrado, no qual cada parte garantia mecanismos de suporte para as outras. Hoehne alertava:

A devastação que se alastra maus augúrios nos insufla. Tombam os gigantes das florestas com as suas cargas de plantas dendrícolas e, aqui e acolá, são formados eucaliptais que pouco recurso para as últimas proporcionam e que muito pouco fazem recordar da nossa maravilhosa terra. (HoEHNE, 1949, p. 124)

Defendia, portanto, a necessidade de preservação da flora nativa, embora isso não significasse que ela não podia ser explorada economicamente, e de forma vantajosa: "Com sabedoria e discernimento pode o homem utilizar-se de tudo sem deixar lacunas. Assim poderá também colher e cultivar Orquidáceas das florestas e dos campos naturais, sem exterminar espécies ou gêneros nas regiões em que a natureza as distribuiu e mantém" (Hoenne, 1949, p. 124).

O propósito do trabalho de Hoehne sobre as orquidáceas era apenas o de despertar o sentido estético e a curiosidade científica, mas também proporcionar conhecimentos mais pragmáticos, relacionados com o tratamento adequado dessas plantas: 
Viajamos convosco, mentalmente, quase todo o nosso grande e belo país. Mostramos onde e como vivem as Orquidáceas na natureza. Justo é, portanto, que transmitamos conselhos aos que, honestamente, se entregam à colheita destas plantas, para que, involuntariamente, não concorram para o abreviamento do seu total desaparecimento, mesmo onde as florestas ainda permanecem. A carência do conhecimento necessário para realizar a colheita, o tratamento preliminar e a embalagem conveniente para o transporte, têm sido, aliás, tão prejudicial à flora orquidológica do nosso torrão, quanto o machado e o facho incendiário. Já mostramos quanto isto concorreu para a perda de grandes e preciosíssimas partidas de plantas, nos primeiros decênios da história da cultura delas nos países europeus. Mas se afirmamos que em nossos dias esses mesmos crimes se repetem, é porque temos acompanhado bem de perto a maneira pela qual continuam sendo colhidas e transportadas as mudas ainda hodiernamente. (HoEHNE, 1949, p. 125)

Hoehne defendia o direito de as gerações futuras continuarem gozando a beleza e a utilidade de um patrimônio natural comum, usando argumentos que ecoam em muitas formulações contemporâneas de proteção à natureza:

Assiste ao homem o direito de usufruir todas as dádivas da natureza. Este privilégio lhe foi outorgado pelo próprio Criador, no dia em que o tornou ser psicozóico, isto é, ente dotado de partícula espiritual. Não devemos olvidar, entretanto, que todo privilégio outorgado também impõe, concomitantemente, responsabilidade e dever. Assim, o Criador, facultando ao homem todo o domínio, lhe ordenou também: "Cultive e guarde". Nunca se deve esquecer que o encontrado como produto da natureza não constitui propriedade privativa, mas patrimônio da coletividade humana e que, justamente por isso, o "Código Florestal do Brasil" acentua, logo no primeiro artigo, que: "As florestas existentes no território nacional, consideradas em conjunto, constituem bem de interesse comum a todos os habitantes do país, exercendo-se os direitos de propriedade com limitação que as leis, em geral e especialmente este Código, estabelecem". Os direitos referidos devem, por isso, ser comuns à geração presente e as advindas. (HoEHNE, 1949, p. 125)

Ao lado da concepção da natureza como uma teia de múltiplas interdependências entre os seres que a constituem, aparece a perspectiva hierárquica, na qual um Criador supremo encarregava o homem, como criatura superior, da administração e cuidado de todos os outros seres constituintes da obra divina. ${ }^{5}$ Desse modo, as estações do ano renovavam ciclicamente

José L. de A. Franco; José A. Drummond. Frederico Carlos Hoehne: viagens e orquídeas 
as atividades biológicas geradoras de energia e estimulavam os humanos a prosseguirem na conquista dos "mais elevados ideais". Essa disposição era manifesta no artigo "Primavera", publicado por Hoehne a respeito da "Festa das Árvores", no jornal A Gazeta, de 21 de setembro de 1946, reproduzido no Relatório Anual do Instituto de Botânica, de 1947. Reconhecia, em primeiro lugar, que havia motivos para o desalento dos muitos que lutaram por instituir uma legislação e medidas relacionadas com a proteção à natureza:

Realmente! Acabrunhado está o coração de muita gente boa e honesta do nosso meio, ao contemplar os tristes espetáculos que se desenrolam diante dos seus olhos, porque lhes parece que seivas de inteligência, programas de previdência, códigos florestais, leis coibitivas das atividades dos famigerados e contumazes dendroclastas, com a boa vontade e o bom senso, ruíram por terra! Afigura-se que milhares de bons preceitos, de excelentes propósitos, de magníficos planos estudados e maturados por uma geração que chega ao seu clímax, são olvidados, estão em risco de se transformarem em objetos dignos de desprezo e de crítica acerba [...]

Sem dúvida, muitos indagam: "Para onde iremos assim?" [...]. Muitos dos que trabalharam com denodo e sacrifício para garantir reservas florestais destinadas a finalidades científicas e econômicas, sentem-se preteridos e exclamam: "Até quando, Senhor, até quando Senhor, repetirse-ão em nosso país, as tentativas para criar uma mentalidade brasílica, para fazer surgir um patriotismo sadio e ativo, capaz de erguer-se contra os desmandos, contra as potestades sinistras que ameaçam transformar o nosso torrão num deserto, numa terra de dendroclastas impenitentes, reiteradores das façanhas de insensatos?!" (HoEHNE, 1947, p. 106-107)

Afigurava-se a Hoehne, no entanto, a necessidade de aproveitar a primavera para renovar o ensejo pela proteção da natureza. Ele depositava as suas esperanças nas gerações mais novas:

Reunindo as forças combalidas, congregando os parcos resíduos no cérebro cansado, pedimos excusas aos que eventualmente pensam de modo diferente concernente aos problemas vitais do Brasil, e lhes solicitamos licença para falarmos aos companheiros da falange dos "Amigos da Flora Brasílica", e muito especialmente aos nobres e beneméritos educadores, mestres de escolas, aos que têm o encargo de dirigir as mentes da geração entrante. Sim, queremos recomendar-lhes que envidem esforços no sentido de criarem os nobres sentimentos nessa gente que vem vindo, nesses homens e mulheres que se vão fazendo, incutindo 
à juventude os deveres sagrados da defesa da natureza brasílica, com a fiel obediência aos códigos e às leis que foram criadas para esse mesmo objetivo. E tudo isso para que vejamos surgir um sintoma de verdadeira brasilidade [...].

Agora que temos novamente a nossa Constituição, é necessário que aprendamos a viver como bons democratas, mas é urgente também que cheguemos a compreender os nossos privilégios e avaliar, devidamente, as nossas responsabilidades de cidadãos brasileiros. (HoEHNE, 1947, p. 107)

Embora o ambiente político tivesse mudado com o fim do Estado Novo e a "redemocratização" do país, a partir de 1945, Hoehne continuava a defender a necessidade uma identidade nacional fundada no sentimento de patriotismo e de respeito ao bem comum. Por meio da educação e da legislação, a sociedade deveria ser conduzida a adotar uma atitude mais previdente em relação ao patrimônio natural. Para tanto, Hoehne reivindicava a atuação firme do Estado e o comprometimento dos cidadãos:

Saudando as escolas públicas e particulares deste grande Estado, incitamos aos seus dirigentes e aos seus professores para usarem os privilégios que thes ficam reservados na formação de mentalidades sadias e previdentes. Incutam no coração da juventude esta grande verdade e este grande aviso: "Constitui crime de lesa-pátria destruir aquilo que é útil e que não pode ser restaurado jamais". Assim são as florestas virgens da nossa terra, estas matas milenárias que a natureza criou e dotou de recursos múltiplos para a ciência, arte, literatura e economia. Uma vez destruídas, não mais poderão ser restauradas com os mesmos elementos e os mesmos recursos [...].

Providências sábias foram tomadas pelos governos passados ao criarem as belas reservas florestais próximas e distantes da nossa Capital e de outros centros mais populosos do nosso Estado. Para que possam assegurar, à geração futura, os recursos biológicos que encerram, é preciso, entretanto, que os nossos homens de agora as façam respeitar. (HoEHne, 1947, p. 107)

Nos anos de 1930, foram criadas uma legislação relacionada com a proteção da natureza e algumas áreas protegidas a título ambiental. Hoehne reconhecia a importância dessas medidas, embora se queixasse da falta de observação da lei. Em sua opinião, era fundamental subordinar os interesses individuais aos da coletividade, que deviam ser pensados levando em conta as gerações futuras. O patriotismo e a valorização da natureza, não só do ponto de vista econômico, mas também de uma perspectiva que envolvesse

José L. de A. Franco; José A. Drummond Frederico Carlos Hoehne: viagens e orquideas 
o interesse científico e a sensibilidade estética, eram vistos como fundamentos necessários da identidade nacional e garantia de perpetuação do patrimônio natural herdado. Boa parte de todo o esforço mais recente de educação ambiental no Brasil usa precisamente esse conjunto de argumentos, mesmo que com outro tom político e outro vocabulário.

Por essas posturas, Hoehne foi e é uma figura importante para aqueles que se preocuparam, em sua época, ou se preocupam, hoje, com a proteção à natureza. Atento às questões pertinentes ao contexto político-intelectual do seu tempo, procurou articular os problemas específicos da conservação da natureza com a questão da identidade nacional. Portanto, justificam-se esforços para recuperar a memória sobre o trabalho e a trajetória de Hoehne. Ressalve-se que não se trata de uma merecida homenagem a um pioneiro datado ou ultrapassado, pois em muitos casos os seus livros e artigos, as suas coleções e as suas propostas contêm materiais relevantes ao estadoda-arte da ciência botânica brasileira e, principalmente, da reflexão sobre a conservação da natureza.

\section{Frederico Carlos Hoehne: travel and orchids}

ABSTRACT: The text uses travel notes written by the Brazilian botanist Frederico Carlos Hoehne (1882-1959) in order to discuss his reflections and aesthethic perspectives related to the protection of nature. It summarizes a long "imaginary" field trip throughout the Brazilian territory, focusing the enormous variety of plants, landscapes, ecosystems and biomes. Hoehne was a pioneer among 20th-century Brazilian scientists in the subject of nature protection. His research and writings aided in the emergence of an early streak of environmental awareness in Brazil, in the 1930s and 1940s. His approach combined science with aesthetic arguments and was base don the assumption that nature should play na important role in the construction of the Brazilian national identity.

KEY WORDS: nature protection, biological diversity, botanical research, History of science, Brazil.

\section{NOTAS}

1 Comparar essa descrição de Alto da Serra feita por Hoehne com a feita por Warren Dean (que visitou o local, já sob o status de parque estadual, provavelmente no início da década de 1990) e constatou um quadro de abandono e destruição, tanto pelo descaso dos gestores quanto pelos efeitos da poluição industrial gerada pelo pólo industrial de Cubatão. Cf. Warren Dean (1996, p. 338-344).

2 O local é hoje protegido pelo Parque Estadual de Vila Velha. 
3 Os dois artigos foram republicados conjuntamente por Frederico Carlos Hoehne em "Sobre a questão dos gafanhotos". Relatório Anual... (1947).

4 Sobre a importância do livro Lagoa Santa, de Eugenio Warming, para a afirmação da ecologia como disciplina científica. Cf. Acot (1990) e Worster (1994).

5 Cf. sobre a discussão dessas perspectivas a respeito da natureza e do papel do homem em relação a ela: Nash (1989), Worster (1994), Acot (1990) e Thomas (1996).

\section{REFERÊNCIAS}

Acot, Pascal. História da ecologia. Rio de Janeiro: Campus, 1990.

Azevedo, Fernando (Org.). As ciências no Brasil, v. 1 e 2. Rio de Janeiro: Ed. UFRJ, 1994.

Barbosa, Lívia Neves de Holanda; Drummond, José Augusto. Os direitos da natureza numa sociedade relacional: reflexões sobre uma nova ética ambiental. Estudos Históricos, Rio de Janeiro, v. 7, n. 14, 1994.

Crosby, Alfred W. Imperialismo ecológico: expansão biológica da Europa (900-1900). São Paulo: Cia. das Letras, 1993.

DEAN, Warren. A ferro e fogo: a história e a devastação da Mata Atlântica brasileira. São Paulo: Cia. da Letras, 1996.

Drummond, José Augusto. Devastação e preservação ambiental no Rio de Janeiro. Niterói: Ed. UFF, 1997.

National Parks in Brazil: A Study of 50 Years of Environmental Policy (With Case Studies of the Parks of the State of Rio de Janeiro). Dissertação (Mestrado) The Evergreen State College. Olympia, W. A., September 1988.

A legislação ambiental brasileira de 1934 a 1988: comentários de um cientista ambiental simpático ao conservacionismo. Ambiente e Sociedade, ano II, n. 3/4, 1998-1999.

História ambiental: temas, fontes e linhas de pesquisa. Estudos Históricos. Rio de Janeiro, v. 4, n. 8, 1991.

Ferri, Mário Guimarães. A botânica no Brasil. Azevedo, Fernando (Org.). As ciências no Brasil, v. 2. Rio de Janeiro: Ed. UFRJ, 1994.

Franco, José Luiz de Andrade. Natureza no Brasil: idéias, políticas, fronteiras (19301992). In: Silva, Luiz Sérgio Duarte da (Org.). Relações cidade-campo: fronteiras. Goiânia: Ed. UFG/Agepel, 2000.

. Proteção à natureza e identidade nacional (1930-1940). 2002. Tese (Doutorado) - Departamento de História da Universidade de Brasília, Brasília, 2002.

. A Primeira Conferência Brasileira de Proteção à Natureza e a Questão da Identidade Nacional. Varia História, Belo Horizonte, v. 26, 2002.

José L. de A. Franco; José A. Drummond. Frederico Carlos Hoehne: viagens e orquídeas 
Franco, José Luiz de Andrade; Drummond, José Augusto. Alberto José Sampaio: um botânico brasileiro e o seu programa de proteção à natureza. Varia História, Belo Horizonte, v. 33, 2005.

. Preocupações com a proteção à natureza e com o uso dos recursos naturais na Primeira República brasileira. Textos de História, Brasília, v. 12, n. 1/2, 2004.

Frederico Carlos Hoehne: a atualidade de um pioneiro no campo da proteção

à natureza no Brasil. Ambiente \& Sociedade, Campinas, v. VIII, n. 1, 2005.

. Armando Magalhães Corrêa: gente e natureza de um sertão quase metropolitano. História, Ciências, Saúde - Manguinhos, Rio de Janeiro, v. 12, n. 3, 2005.

Gomes, Angela de Castro. História e historiadores. Rio de Janeiro: Ed. FGV, 1996.

Holanda, Sérgio Buarque de. Raízes do Brasil. Rio de Janeiro: José Olympio, 1979.

Hoenne, Frederico Carlos. As plantas ornamentaes da flora brasílica, v. I. São Paulo: Secretaria de Agricultura, Indústria e Comércio, 1930.

Resenha histórica para a comemoração do vigésimo aniversário da Seção de Botânica e Agronomia anexa ao Instituto Biológico de São Paulo. São Paulo: Secretaria de Agricultura, Indústria e Comércio, 1937.

As plantas ornamentaes da flora brasílica, v. II. São Paulo: Secretaria de Agricultura, Indústria e Comércio, 1936.

Relatório anual do Instituto de Botânica, n. de 1943 a 1951. São Paulo: Secretaria de Agricultura.

São Paulo, 1949.

Iconografia das orchidáceas do Brasil. São Paulo: Instituto de Botânica de

LENOBLE, Robert. História da idéia de natureza. Lisboa: Edições 70, 1990.

LEONARDI, Victor. Entre árvores e esquecimentos: história social nos sertões do Brasil. Brasília: Ed. UnB/Paralelo 15, 1996.

MaYr, Ernst. O desenvolvimento do pensamento biológico. Brasília: Ed. UnB, 1998.

McCoRmick, John. Rumo ao paraíso: a história do movimento ambientalista. Rio de Janeiro: Relume-Dumará, 1992.

NASH, Roderick. The Rights of Nature: a history of environmental ethics. Wisconsin: Wisconsin University Press, 1989.

NogueIra, Eliana. Uma história brasileira da botânica. Brasília/São Paulo: Paralelo 15/Marco Zero, 2000.

Ortiz, Renato. Cultura brasileira e identidade nacional. São Paulo: Brasiliense, 1985. PÁDUA, José Augusto. Um sopro de destruição: pensamento político e crítica ambiental no Brasil escravista (1786-1888). Rio de Janeiro: Jorge Zahar, 2002.

Pécaut, Daniel. Os intelectuais e a política no Brasil: entre o povo e a nação. São Paulo: Ática, 1990. 
Pereira, Osny Duarte. Direito florestal brasileiro (Ensaio). Rio de Janeiro: Borsoi, 1950.

Thomas, Keith. O homem e o mundo natural. São Paulo: Cia. das Letras, 1996.

URBAn, Teresa. Saudade do Matão: relembrando a história da conservação da natureza no Brasil. Curitiba: Ed. UFPR/Boticário/MacArthur Foundation, 1998.

Worster, Donald. Nature's Economy: a history of ecological ideas. Cambridge: Cambridge University Press, 1994.

The Wealth of Nature: environmental history and the ecological imagination. New York: Oxford Press, 1993.

José L. de A. Franco; José A. Drummond. Frederico Carlos Hoehne: viagens e orquídeas 